\title{
EKSTRAKSI KATEKIN DARI BIJI ALPUKAT DENGAN VARIASI PELARUT MENGGUNAKAN METODE MASERASI
}

\author{
I K. N. Sanjaya*, N. K. M. Giantari, M. D. Widyastuti, dan N. P. L. Laksmiani \\ Program Studi Farmasi, Fakultas Matematika dan Ilmu Pengetahuan Alam, \\ Universitas Udayana, Jimbaran, Badung, Bali, Indonesia \\ *Email: nikosanjaya98@gmail.com
}

\begin{abstract}
ABSTRAK
Buah alpukat merupakan salah satu buah yang digemari banyak orang karena rasa dan kandungan yang dimiliki oleh buah alpukat. Alpukat mengandung antioksidan dan zat gizi seperti lemak yaitu 9,8 g/100 g daging buah. Namun hingga kini, pemanfaatan alpukat masih terfokus pada bagian buah sedangkan bagian lain seperti biji kurang dimanfaatkan. Katekin merupakan senyawa golongan flavonoid yang terkandung dalam biji alpukat. Ekstraksi katekin dalam biji alpukat dilakukan dengan metode maserasi yaitu perendaman menggunakan tiga variasi pelarut yaitu etil asetat, etanol 95\%, dan aseton selama 24 jam. Hasil maserasi disaring kemudian dilakukan remaserasi selama 24 jam untuk memperoleh filtrat yang lebih banyak, kemudian dipekatkan dengan rotary vaccum evaporator untuk memperoleh ekstrak kental biji alpukat yang selanjutnya diuji kadarnya menggunakan metode KLT-Densitometri. Hasil yang diperoleh yaitu kadar katekin tertinggi diperoleh pada maserasi menggunakan pelarut etil asetat yaitu dengan kadar sebesar 25,55\% b/b.
\end{abstract}

Kata kunci: biji alpukat, katekin, maserasi

\begin{abstract}
Avocado is one of the fruits favored by many people because of the avocado's taste and content. Avocados contain antioxidants and nutrients such as fat which is $9.8 \mathrm{~g} / 100 \mathrm{~g}$ of fruit flesh. But until now, the use of avocados is still focused on the fruit while other parts such as seeds are underutilized. Catechins are flavonoid compounds contained in avocado seeds. Extraction of catechins in avocado seeds was carried out by maceration method, namely immersion using three variations of solvents namely ethyl acetate, 95\% ethanol, and acetone for 24 hours. The results of maceration were filtered and then remaserated for 24 hours to obtain more filtrate, then concentrated with an evaporator rotary vaccum to obtain thick extracts of avocado seeds which were then tested using the TLC-Densitometry method. The results obtained were the highest levels of catechins obtained in maceration using ethyl acetate solvents, with levels of $25.55 \% \mathrm{~b} / \mathrm{b}$.
\end{abstract}

Keywords: avocado seeds, catechins, maceration

\section{PENDAHULUAN}

Alpukat merupakan tanaman yang dapat tumbuh subur di daerah tropis seperti Indonesia. Buah alpukat merupakan salah satu buah yang digemari banyak orang karena rasa dan kandungan yang dimiliki oleh buah alpukat. Alpukat mengandung antioksidan dan zat gizi seperti lemak sebesar 9,8 g/100 g daging buah (Afrianti, 2010). Namun hingga kini, pemanfaatan alpukat masih terfokus pada bagian buah sedangkan bagian lain seperti biji kurang dimanfaatkan.
Biji alpukat mengandung saponin $(51.00 \pm 0.00)$, tanin $(21.66 \pm 0.00)$, flavonoid $(21.00 \pm 0.00)$, alkaloid $(9.43 \pm 0.20)$ dan sianogenik glikosida $(4.86 \pm 0.00)$. Selain itu biji alpukat juga mengandung 15\% - 20\% minyak yang dapat dimanfaatkan sebagai pelembab alami pada kulit. Kandungan flavonoid dalam biji alpukat yang telah dilaporkan berupa katekin yaitu flavan-3-ol (Steenis, 2003).

Katekin merupakan metabolit sekunder yang termasuk flavonoid golongan flavan-3-ol yang paling luas penyebarannya di alam. 
Katekin bersifat asam lemah, sangat tidak stabil di udara terbuka, mudah teroksidasi pada $\mathrm{pH}$ mendekati netral ( $\mathrm{pH} 6,9)$, serta lebih stabil pada $\mathrm{pH} 2,8$ dan $\mathrm{pH}$ 4,9. Katekin memiliki kelarutan yaitu larut dalam alkohol dingin, etil asetat, air panas, asam asetat glasial dan asetom (Lucida dkk., 2007).

Ekstraksi merupakan salah satu metode pemisahan zat terlarut dengan pelarut yang didasarkan pada titik didih pelarut. Ekstraksi menggunakan pelarut berdasarkan kelarutan komponen terhadap komponen lainnya atau polaritasnya dalam campuran. Salah satu metode ekstraksi yang umum digunakan adalah maserasi. Maserasi merupakan cara ekstraksi yang paling sederhana yaitu dengan melarutkan serbuk simplisia ke dalam pelarut pengekstraksi.

Pemilihan metode ekstraksi pada penelitian ini karena senyawa katekin rentan terhadap panas sehingga tidak baik jika diekstraksi menggunakan metode ekstraksi seperti soxhlet dan refluks. Penelitian Cheong et al. (2005) menyatakan bahwa konsentrasi senyawa katekin yang diekstraksi menggunakan metode soxhlet mengalami penurunan jika dibandingkan dengan metode ekstraksi.

Oleh karena itu, pada penelitian ini dilakukan ekstraksi biji alpukat menggunakan metode maserasi dengan variasi pelarut untuk melihat pelarut yang paling optimum menghasilkan kadar senyawa katekin yang tertinggi.

\section{BAHAN DAN METODE}

\section{Bahan}

Bahan yang digunakan pada penelitian ini adalah biji alpukat, etil asetat, etanol $95 \%$, aseton, metanol, toluena, asam format, plat KLT silika gel GF 254

\section{Alat}

Alat yang digunakan pada penelitian ini adalah toples kaca, batang pengaduk, labu ukur, pipet ukur, cawan porselen, rotary vaccum evaporator, KLT-Densitometer.

\section{Metode Penelitian \\ Preparasi Bahan}

Biji alpukat yang telah dikumpulkan dikupas kulit bijinya kemudian dicuci hingga bersih. Selanjutnya biji alpukat diiris tipis- tipis untuk memudahkan dalam pengeringan. Irisan biji alpukat selanjutnya dikeringkan di dalam oven dengan suhu $60^{\circ} \mathrm{C}$ hingga kering. Irisan biji alpukat yang telah kering kemudian dihaluskan dengan blender hingga menjadi serbuk biji alpukat.

\section{Ekstraksi Biji Alpukat}

Serbuk biji alpukat yang telah diperoleh diekstraksi menggunakan metode maserasi dengan menggunakan variasi pelarut. Pelarut yang digunakan yaitu etil asetat, aseton, dan etanol 95\% dengan perbandingan 1:10 b/v. Serbuk biji alpukat masing-masing ditimbang sebanyak 100 gram kemudian dimasukkan ke dalam masing-masing toples. Selanjutnya dimaserasi dengan masing-masing pelarut yang digunakan sebanyak $1000 \mathrm{~mL}$ dan diaduk perlahan. Ekstrak didiamkan selama 24 jam kemudian disaring hingga diperoleh ekstrak hasil maserasi. Selanjutnya dilakukan proses remaserasi dengan masing-masing pelarut sebanyak $1000 \mathrm{~mL}$ dan didiamkan kembali selama 24 jam. Setelah 24 jam, ekstrak disaring hingga diperoleh ekstrak hasil remaserasi.

Ekstrak hasil maserasi dan hasil remaserasi kemudian dicampur dan diuapkan pelarutnya menggunakan rotary evaporator. Ekstrak hasil penguapan selanjutnya diuapkan kembali di dalam oven dengan suhu $60^{\circ} \mathrm{C}$ hingga diperoleh ekstrak kental.

\section{Identifikasi Katekin pada Ekstrak}

Identifikasi senyawa katekin pada masing-masing ekstrak kental biji alpukat dengan variasi pelarut (etil asetat, aseton, dan etanol 95\%) dilakukan dengan menggunakan metode KLT-Densitometri. Tahapan penelitiannya adalah pembuatan larutan standar katekin dengan konsentrasi $1 \mathrm{mg} / \mathrm{mL}$, kemudian pembuatan larutan seri dengan variasi konsentrasi $20,40,80,160$, dan 320 ppm. Selanjutnya adalah penyiapan fase diam yaitu plat KLT silika gel GF 254 dengan ukuran $20 \times 10 \quad \mathrm{~cm}$. Fase gerak yang digunakan yaitu toluena:etil asetat:asam format:metanol $(3: 6: 1,6: 0,4) \mathrm{v} / \mathrm{v} / \mathrm{v} / \mathrm{v}$ sebanyak $35 \mathrm{~mL}$. Preparasi larutan sampel dilakukan dengan menimbang ekstrak kental sebanyak 1 g kemudian dilarutkan dalam $10 \mathrm{~mL}$ metanol.

Larutan seri dan ketiga larutan sampel yang telah dipreparasi kemudian ditotolkan menggunakan automatic sampler dengan 
volume penotolan larutan seri $5 \mu \mathrm{L}$ dan volume totolan untuk larutan sampel adalah 5 $\mu \mathrm{L}, 10 \mu \mathrm{L}, 15 \mu \mathrm{L}$ pada plat KLT yang telah dicuci dengan metanol dan diaktivasi pada suhu $110^{\circ} \mathrm{C}$ selama 15 menit. Plat KLT kemudian dielusi menggunakan fase gerak yaitu toluena:etil asetat:asam format:metanol (3:6:1,6:0,4) v/v/v/v sebanyak $35 \mathrm{~mL}$. Setelah elusi selesai, plat KLT discan pada KLTDensitometri dengan panjang gelombang 200 nm sampai $400 \mathrm{~nm}$.

\section{HASIL DAN PEMBAHASAN}

Penelitian yang telah dilakukan untuk mengetahui pengaruh jenis pelarut terhadap hasil ekstraksi katekin dari biji alpukat terlihat bahwa terdapat pengaruh jenis pelarut terhadap kadar katekin yang diperoleh. Pada penelitian ini menggunakan tiga variasi pelarut yaitu etil asetat, etanol 95\%, dan aseton. Pemilihan pelarut ini didasarkan atas kelarutan senyawa katekin pada pelarut tersebut, mudah dipisahkan, dan dimurnikan kembali (Damanik et al., 2014).

Analisis kualitatif dan kuantitatif dari ekstrak yang diperoleh dilakukan dengan metode Kromatografi Lapis TipisDensitometri (KLT-Densitometri). Analisis kualitatif dilakukan dengan metode KLT dengan melihat spektrum dan nilai Rf yang dihasilkan, sedangkan analisis kuantitatif dilakukan menggunakan instrumen densitometer dengan melihat nilai AUC sehingga dapat ditentukan kadar senyawa katekin dalam ekstrak biji alpukat.

Berdasarkan hasil pada Gambar 1 menunjukkan bahwa katekin standar menghasilkan $\operatorname{Rf} 0,6$ dan pada totolan sampel terdapat spot dengan $\operatorname{Rf} 0,6$ pula. Hal ini mengindikasikan terdapatnya senyawa yang sama pada jarak migrasi tersebut. Hasil kromatografi dianalisis dengan metode densitometri.

Warna ungu menunjukkan spektrum katekin standar, warna merah muda (pink) menunjukkan spektrum ekstrak etanol biji alpukat, warna biru menunjukkan spektrum ekstrak etil asetat biji alpukat, dan warna hijau menunjukkan ekstrak aseton biji alpukat.

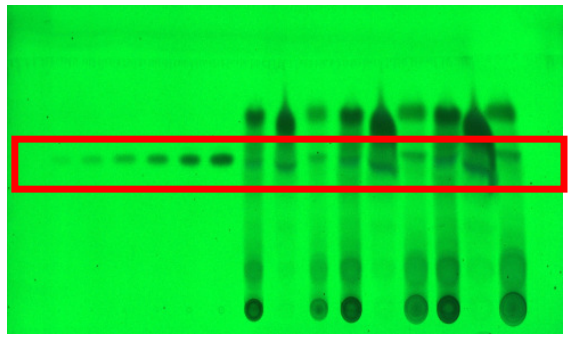

(a)

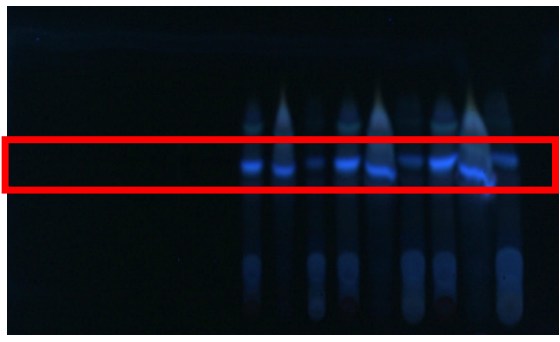

(b)

Gambar 1 (a) Analisis plat kromatografi lapis tipis pada panjang gelombang $254 \mathrm{~nm}$, (b) Analisis plat kromatografi lapis tipis pada panjang gelombang $366 \mathrm{~nm}$.

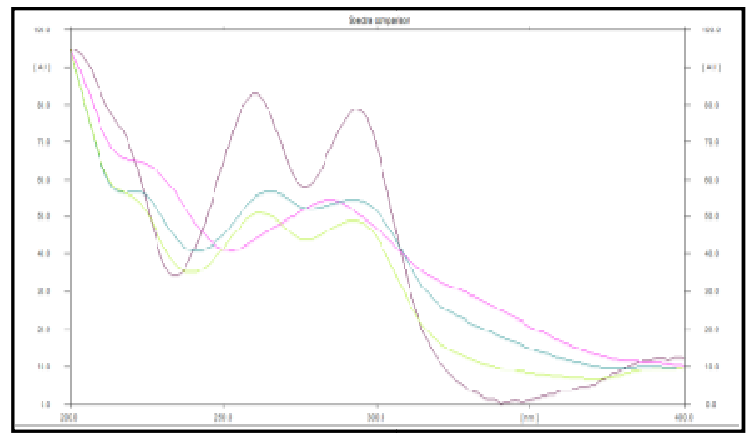

Gambar 2. Overlapping Spectrum ekstrak Biji Alpukat dan Katekin Standar.

Pada Gambar 2 menunjukkan spektrum ekstrak etil asetat biji alpukat dan ekstrak aseton biji alpukat sesuai dengan spektrum katekin standar, sehingga diduga katekin terkandung dalam ekstrak tersebut. Spektrum ekstrak etanol biji alpukat tidak sesuai dengan spektrum katekin standar, dapat disebabkan karena pada struktur etanol terdapat gugus cenderung polar dan gugus cenderung non polar sehingga memiliki kemampuan pula untuk menarik komponen lain atau pengotor dan berpengaruh terhadap spektrum hasil pengukuran. 
Tabel 1. Hasil Pengukuran KLT-Densitometri.

\begin{tabular}{llll}
\hline \multicolumn{1}{c}{ Larutan } & Totolan & Rf & AUC \\
\hline Seri 1 & $100 \mathrm{ng}$ & 0,6 & 92,5 \\
Seri 2 & $200 \mathrm{ng}$ & 0,6 & 168,2 \\
Seri 3 & $400 \mathrm{ng}$ & 0,6 & 269,1 \\
Seri 4 & $800 \mathrm{ng}$ & 0,6 & 398,7 \\
Seri 5 & $1200 \mathrm{ng}$ & 0,6 & 524,8 \\
Seri 6 & $1600 \mathrm{ng}$ & 0,6 & 605,6 \\
Ekstrak etanol & $5000 \mathrm{ng}$ & 0,6 & 452,7 \\
Ekstrak etil asetat & $5000 \mathrm{ng}$ & 0,6 & 531,2 \\
Ekstrak aseton & $5000 \mathrm{ng}$ & 0,6 & 345,7 \\
\hline
\end{tabular}

Berdasarkan hasil nilai AUC dan konsentrasi totolan, diperoleh persamaan regresi linear yaitu $\mathrm{y}=0,3352 \mathrm{x}+102,96$ dengan nilai korelasi sebesar 0,9743. Berdasarkan persamaan regresi linear tersebut, maka dapat dihitung kadar senyawa katekin pada ekstrak etanol, ekstrak etil asetat, dan ekstrak aseton seperti pada Tabel 2.

Tabel 2. Kadar Katekin pada Masing-Masing Ekstrak.

\begin{tabular}{lc}
\hline \multicolumn{1}{c}{ Ekstrak } & Kadar \\
\hline Ekstrak etanol & $20,87 \% \mathrm{~b} / \mathrm{b}$ \\
Ekstrak etil asetat & $25,55 \% \mathrm{~b} / \mathrm{b}$ \\
Ekstrak aseton & $14,48 \% \mathrm{~b} / \mathrm{b}$ \\
\hline
\end{tabular}

Tabel 2 menunjukkan bahwa kadar senyawa katekin yang tertinggi berada pada ekstrak biji alpukat dengan pelarut etil asetat. Hal ini sesuai dengan penelitian Sousa (2008) yang menyatakan bahwa pemilihan pelarut yang terbaik pada proses senyawa yang akan diekstrak adalah pelarut yang mudah dipisahkan (menguap) dan dimurnikan kembali. Diantara ketiga pelarut yang digunakan, pelarut yang paling mudah menguap adalah etil asetat sehingga hal ini menjadi dasar bahwa kadar senyawa katekin yang tertinggi berada pada ekstrak bihi alpukat dengan pelarut etil asetat.

\section{SIMPULAN}

Kadar katekin tertinggi diperoleh dari pelarut etil asetat dengan kadar sebesar 25,55 $\% \mathrm{~b} / \mathrm{b}$.

\section{UCAPAN TERIMA KASIH}

Penulis mengucapkan terima kasih kepada dosen pembiming, keluarga, temanteman, dan semua pihak yang telah membantu dan mendukung dalam penelitian ini.

\section{DAFTAR PUSTAKA}

Afrianti, L. H. 2010. Macam Buah-Buahan untuk Kesehatan. Bandung: Alfabeta.

Cheong, M. H, Park, M. H., Kang, G. W, Ko, J, H, and Seo, Y, J. 2005. Determination of Catechin Compounds in Korea Green Tea Influsions Under Varios Extraction Condition by High Performance Liquid Chomatrography. Bulletin of The Korea Chemical Society 26. (5): 747-754.

Damanik, D. D. P., Nurhayati, S., Rosdanelli, H. 2014. Ekstraksi Katekin dari Daun Gambir (Uncaria gambir roxb) dengan Metode Maserasi. Jurnal Teknik Kimia USU. 3(2): 10-14.

Lucida, H., A. Bakhtiar., dan W. A. Putri. 2007. Formulasi Sediaan Antiseptik Mulut dari Katekin Gambir. Jurnal Sains Teknologi Farmasi. 12(1): 41-47.

Sousa, A., dkk. 2008. Effect Of Solvent And Extraction Temperatures On The Antioxident Potential of Traditional Stoned Table Olives Alcaparras. (41):739-745, Diahlibahasakan oleh Liris Mahadewi Rachimullah. Universitas Muhamadiyah, Surakarta.

Steenis, C. G. G. J. 2003. Flora. Jakarta: PT Pradnya Paramita. 